\title{
Coronary Palmaz-Schatz stent implantation in acute myocardial infarction
}

\author{
F-J Neumann, H Walter, G Richardt, C Schmitt, A Schömig
}

\begin{abstract}
Objective-To investigate the feasibility of coronary stenting in acute myocardial infarction.

Design-Prospective observational study. Patients-80 patients undergoing direct balloon angioplasty for acute myocardial infarction who had coronary PalmazSchatz stents implanted during a 3 year study period. Indications for stenting were abrupt reocclusion, large dissection with threatened reocclusion, and failure to achieve brisk flow of contrast by angioplasty alone.

Interventions-After stenting, 50 patients were treated by conventional anticoagulation and 30 patients received antiplatelet therapy with aspirin and ticlopidine.
\end{abstract}

Main outcome measures-Death and subacute reocclusion within two weeks.

Results-Coronary stenting fully restored vessel patency in 79 patients $(98 \cdot 8 \%) .10$ of 14 patients with symptoms of Killip class IV on admission were discharged from hospital alive. Three of the 66 patients with symptoms of Killip classes I-III died in hospital. Repeat angiography in 59 of these patients, showed 3 symptomatic and 2 silent reocclusions (reocclusion rate $8 \cdot 5 \%)$. No stent thromboses were detected in patients treated with ticlopidine.

Conclusions-Coronary stenting is a safe and effective treatment for complicated direct balloon angioplasty in acute myocardial infarction. In patients with symptoms of Killip classes I to III the risk of subacute reocclusion is comparable to that of bail-out stenting after elective balloon angioplasty.

(Heart 1996;75:121-126)

Keywords: coronary stents; acute myocardial infarction; balloon angioplasty; thrombosis

1. Medizinische Klinik, Technische Universität München, Germany F-J Neumann $\mathrm{H}$ Walter G Richardt C Schmitt A Schömig Correspondence to: Dr F-J Neumann, 1 Medizinische Klinik der Technischen Universität München, Klinikum rechts der Isar, Ismaninger Strasse 22, 81675 München, Germany.

Accepted for publication 19 October 1995 goal than thrombolysis. ${ }^{4-6}$ Nevertheless, serious concerns remain with direct PTCA Failure to achieve reperfusion is rare with this approach but it carries a high mortality $(31 \%-43 \%)^{7-9}$ that reaches $78 \%$ when com-

In acute myocardial infarction, early, complete, and sustained restoration of blood me occluded coronary artery can salvage Controlled trials have shown that direct percutaneous transluminal balloon angioplasty $(31 \%-43 \%)^{7-9}$ that reaches $78 \%$ when com- bined with cardiogenic shock. ${ }^{2}$ Moreover, reocclusion occurs in $10 \%-15 \%$ of the patients after successful direct PTCA. ${ }^{1012}$ Though reocclusion is often asymptomatic, ${ }^{10-12}$ it abrogates most of the benefit from timely reperfusion. ${ }^{3810}$ Previous studies suggest that the risk of reocclusion is particularly high when coronary blood flow continues to be compromised after recanalisation ${ }^{1314}$ or when PTCA results in large dissections. ${ }^{15} 16$

In elective PTCA the implantation of an intracoronary stent is an established treatment for present or threatened vessel closure. ${ }^{17-19}$ Early clinical experience with coronary stenting, however, suggested a high rate of stent thrombosis in acute myocardial infarction. ${ }^{2021}$ Moreover, acute vessel closure before stent delivery ${ }^{1822}$ and intraluminal thrombosis have been identified as predictors of subacute stent occlusion. ${ }^{23-25}$ Accordingly, the risk of stent thrombosis in acute myocardial infarction is generally considered to be prohibitive ${ }^{26}$ and published experience with coronary stents in this setting remains anecdotal. ${ }^{26-28}$ Thus we are still uncertain of the potential of coronary stenting to optimise coronary artery patency in acute myocardial infarction.

This report summarises clinical and angiographic follow-up data on 80 patients with Palmaz-Schatz stent implantation for treatment or prevention of coronary reocclusion after direct PTCA in acute myocardial infarction.

\section{Patients and methods}

PATIENT SELECTION

We studied 80 patients who were treated by intracoronary Palmaz-Schatz stent implantation after direct PTCA in acute myocardial infarction between 1 May 1992 and 30 April 1995. All 80 presented within $48 \mathrm{~h}$ of the onset of pain. Indications for stenting were inability to maintain Thrombolysis in Myocardial Infarction (TIMI) grade $3 \mathrm{flow}^{29}$ by direct PTCA alone, abrupt reocclusion, or large dissection with threatened reocclusion. Small vessel size ( $\leqslant 2.0 \mathrm{~mm}$ diameter) was the only contraindication for stenting and we implanted stents irrespective of angiographic evidence of persistent thrombus, lesion length, or length of dissection. Diagnosis of acute myocardial infarction was based on the presence of at least three of the following criteria: (a) severe anginal pain lasting more than 30 minutes that was refractory to antianginal medication, (b) ST segment elevation of $\geqslant 0 \cdot 1$ $\mathrm{mV}$ in two or more contiguous leads, $(c)$ rise in 
serum creatine kinase activity of $>100 \mathrm{U} / 1$ with a concomitant rise in $\mathrm{MB}$ isoenzyme to $\geqslant 8 \%$ of the total creatine kinase activity, $(d)$ coronary artery occlusion with angiographic appearance suggestive of fresh thrombus. Table 1 shows the baseline characteristics of the study population. Symptoms were graded as Killip class I in 52, class II in 12, and class III in $2 .{ }^{30}$ Fourteen patients presented with symptoms of Killip class IV. ${ }^{30}$ All of them had signs of cardiogenic shock. In addition to systemic hypotension (systolic blood pressure $<90 \mathrm{~mm} \mathrm{Hg}$ ), all had severe pulmonary congestion and 12 had to be mechanically ventilated before the intervention. In seven of these patients, whose condition did not improve immediately after the intervention, cardiogenic shock was confirmed by invasive haemodynamic monitoring (cardiac index $\leqslant 2 \cdot 0$ $1 / \mathrm{min} / \mathrm{m}^{2}$, pulmonary capillary wedge pressure $\geqslant 18 \mathrm{~mm} \mathrm{Hg}$ ).

The study population represented $22 \%$ of all patients undergoing direct PTCA for acute myocardial infarction (fig 1). During the study period, direct PTCA was the treatment of choice for acute myocardial infarction in patients presenting within 12 hours after onset of pain and, thereafter, if symptoms of myocardial ischaemia persisted (fig 1).

Patients or their relatives gave informed consent before the qualifying procedure. The

Table 1 Baseline characteristics of study patients

\begin{tabular}{lcc}
\hline & $\begin{array}{l}\text { Killip classes I to III } \\
(n=66)\end{array}$ & $\begin{array}{l}\text { Killip class IV } \\
(\mathrm{n}=14)\end{array}$ \\
\hline Male/female & $51 / 15$ & $8 / 6$ \\
Mean (SD) age (y) (range) & $59 \cdot 3(10 \cdot 7)(37-82)$ & $68 \cdot 0(14 \cdot 0)(36-96)$ \\
Active smokers (n (\%)) & $36(54 \cdot 5)$ & $5(35 \cdot 7)$ \\
Hypercholesterolaemia (n (\%)) & $45(68 \cdot 2)$ & $6(42 \cdot 8)$ \\
Systemic hypertension (n (\%)) & $32(48.5)$ & $5(35 \cdot 7)$ \\
Diabetes mellitus (n (\%)) & $17(25 \cdot 8)$ & $3(21 \cdot 4)$ \\
Prior myocardial infarction (n (\%)) & $13(19 \cdot 7)$ & $4(28 \cdot 6)$ \\
Vessel disease: & $30(45 \cdot 5)$ & $6(42 \cdot 9)$ \\
Single (n (\%)) & $19(28 \cdot 8)$ & $5(35 \cdot 7)$ \\
Double (n (\%)) & $17(25.6)$ & $3(21 \cdot 4)$ \\
Triple (n (\%)) & $1256(1501)$ & $2407(2312)$ \\
Peak CK (U/) (mean (SD)) & $28(42 \cdot 4)$ & 14 \\
Pain to intervention (h): & $19(28.9)$ & 0 \\
<6 & $19(28 \cdot 9)$ & 0 \\
6-12 & & \\
$12-48$ & & \\
\hline
\end{tabular}

CK, creatine kinase.

Table 2 Procedural characteristics and primary angiographic results

\begin{tabular}{|c|c|c|}
\hline & $\begin{array}{l}\text { Killip Classes I to III } \\
(n=66)\end{array}$ & $\begin{array}{l}\text { Killip Class IV } \\
(\mathbf{n}=14)\end{array}$ \\
\hline \multicolumn{3}{|l|}{ Target vessel (n (\%)): } \\
\hline LM & 0 & $3(21 \cdot 4)$ \\
\hline $\mathrm{LAD}$ & $26(39 \cdot 4)$ & $3(21 \cdot 4)$ \\
\hline $\mathrm{LCx}$ & $8(12 \cdot 1)$ & $5(35.7)$ \\
\hline RCA & $29(43.9)$ & $9(64 \cdot 3)$ \\
\hline \multirow{2}{*}{\multicolumn{3}{|c|}{$\begin{array}{l}\text { Venous bypass graat } \\
\text { Indication for stenting ( }(\%) \text { ): }\end{array}$}} \\
\hline & & \\
\hline Reclosure & $6(9 \cdot 1)$ & $1(7 \cdot 1)$ \\
\hline TIMI grade 2 & $17(25 \cdot 8)$ & $7(50 \cdot 0)$ \\
\hline Dissection & $43(65 \cdot 2)$ & $6(42.9)$ \\
\hline Residual thrombus after PTCA (n (\%)) & $24(36 \cdot 4)$ & $5(35 \cdot 7)$ \\
\hline Reference diameter $(\mathrm{mm})^{\star}$ & $3.04(0.69)$ & $3.34(0.62)$ \\
\hline Maximal inflation pressure (atm) ${ }^{\star}$ & $14.8(2 \cdot 87)$ & $16.0(1.51)$ \\
\hline Balloon/vessel ratio* & $1.02(0.17)$ & $1.11(0.11)$ \\
\hline Minimal luminal diameter after $(\mathrm{mm})^{\star}$ & $2.89(0.62)$ & $3.13(0.65)$ \\
\hline Diameter stenosis after $(\%)^{\star}$ & $9.5(13.9)$ & $6.4(8 \cdot 0)$ \\
\hline Multiple stent patients (n (\%)) & $33(50)$ & $10(71 \cdot 4)$ \\
\hline
\end{tabular}

LAD, left anterior descending coronary artery; LCx, left circumflex coronary artery; LM, left main coronary artery; PTCA, percutaneous transluminal coronary angioplasty; RCA, right coronary artery; and TIMI, Thrombolysis in Myocardial Infarction.

$\star$ Mean (SD). study was approved by the institute's ethics committee.

\section{STENTING PROCEDURE AND POST-STENTING} MANAGEMENT

PTCA was performed by the femoral approach using 7 French sheaths. Before the intervention, all patients were given intravenous bolus injections of 5000 IU heparin and $1 \mathrm{~g}$ aspirin; an additional dose of 10000 IU heparin was injected intra-arterially after obtaining vascular access. Given the indication, Palmaz-Schatz stents (Johnson \& Johnson Interventional Systems, Warren, NJ) were hand-crimped onto the angioplasty balloon (mostly Dual Express, Scimed Life Systems) and deployed as described in detail earlier. ${ }^{18}$ When feasible, we tried to optimise stent expansion by additional balloon inflations with short $(10 \mathrm{~mm})$ balloons (High Energy, Boston Scientific) and high inflation pressures (table 2), but we did not use intracoronary ultrasound. ${ }^{31-33}$ We did not administer intracoronary thrombolytic agents after successful stenting. We removed the arterial sheath within the first four hours after the intervention, as soon as the activated partial prothrombin time fell below $80 \mathrm{~s}$.

After sheath removal, 42 patients were put on conventional anticoagulation with heparin, phenprocoumon, and aspirin, $2 \times 100 \mathrm{mg} /$ day (table 3). ${ }^{1834}$ Heparin infusion was restarted immediately and titrated to maintain the activated partial prothrombin time between $80 \mathrm{~s}$ and $120 \mathrm{~s}$. Treatment with the vitamin $\mathrm{K}$ antagonist phenprocoumon (Marcumar, Hoffmann-La Roche, GrenzachWyhlen, Germany) was begun on the day of the intervention. We continued the heparin infusion for 5-10 days until we achieved a stable level of oral anticoagulation at an international normalised ratio for prothrombin time between 3.0 and 4.5 . If no other indication for anticoagulation was present, we stopped the vitamin $\mathrm{K}$ antagonist after four

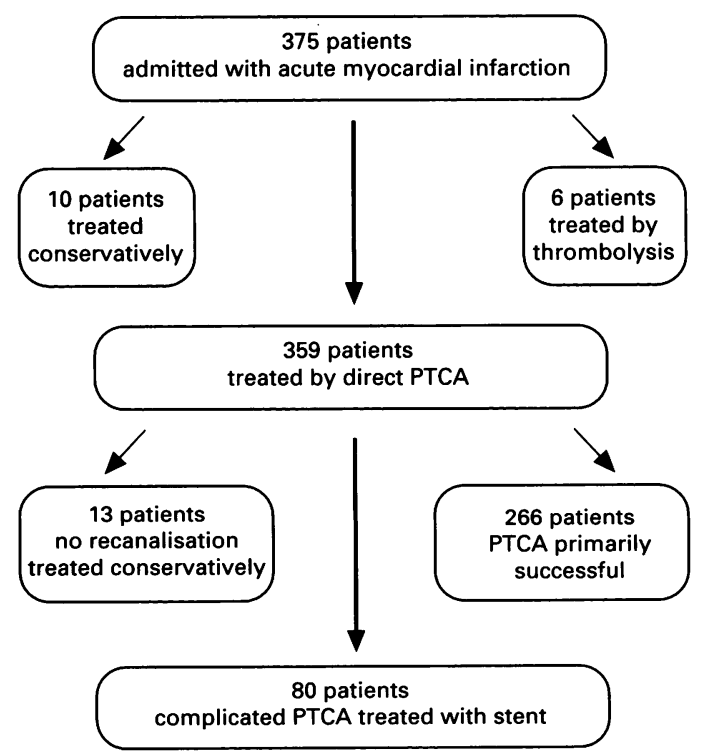

Figure 1 Treatment for patients admitted with acute myocardial infarction. 
Table 3 Post-stenting antithrombotic treatment

\begin{tabular}{lcc}
\hline & $\begin{array}{l}\text { Killip classes I to III } \\
(n=66)\end{array}$ & $\begin{array}{l}\text { Killip class IV } \\
(\mathrm{n}=14)\end{array}$ \\
\hline $\begin{array}{l}\text { Aspirin plus heparin alone (n (\%)) } \\
\text { Aspirin plus heparin and phenprocoumon (n (\%)) }\end{array}$ & $38(6 \cdot 1)$ & $5(35 \cdot 7)$ \\
Aspirin plus ticlopidine (n (\%)) & $25(36 \cdot 1)$ & $4(28 \cdot 6)$ \\
\hline
\end{tabular}

For dosages refer to the methods section.

weeks. Eight patients who had contraindications to phenprocoumon or were potential candidates for emergency cardiac surgery were treated by full dose heparin and aspirin only.

Because of the favourable experience with antiplatelet therapy alone, ${ }^{33} 3536$ from May 1994 onwards 30 patients received $2 \times 250$ mg ticlopidine plus $2 \times 100 \mathrm{mg}$ aspirin instead of conventional anticoagulation.

FOLLOW-UP AND OUTCOME MEASURES

Patients remained in hospital for at least 14 days. Eight weeks and six months after discharge they were reassessed to monitor subsequent events. All surviving patients were scheduled for repeat coronary angiography, which was performed before discharge or at subsequent follow up visits. Six months clinical follow up was complete for all patients except one who presented in Killip class II and was lost to follow up after being discharged from hospital on day 15 .

Outcome measures were angiographic procedural success, angiographic evidence of reocclusion of the stented segment, reinfarction, and cardiac death. Angiographic procedural success was defined by TIMI grade 3 flow with reduction of diameter stenosis to less than $50 \%$, and reinfarction was defined as recurrent chest pain lasting more than $30 \mathrm{~min}$ utes with new ST segment elevation and either emergency angiographic confirmation of an occluded vessel or recurrent elevation of cardiac enzymes. Angiograms were evaluated by computerised quantitative coronary angiography, as reported elsewhere. ${ }^{18}$

\section{STATISTICAL ANALYSIS}

Results are reported as mean (SD) or percentages, as appropriate. Survival was assessed by the Kaplan-Meier method. To compare frequencies we used Fisher's exact test. Values of $P<0.05$ in the two tailed test were regarded as significant. Because there were marked differences in the natural course in patients with symptoms of Killip class IV compared with those with symptoms in classes I to III, we analysed survival and reocclusion rates of these patient groups separately.

Table 4 Major cardiac events

\begin{tabular}{lll}
\hline & $\begin{array}{l}\text { Killip classes I to III } \\
(n=66)\end{array}$ & $\begin{array}{l}\text { Killip class IV } \\
(\mathrm{n}=14)\end{array}$ \\
\hline In hospital: & $3(4 \cdot 5)$ & $4(28 \cdot 6)$ \\
$\quad$ Cardiac death (n (\%)) & $1(1 \cdot 5)$ & 0 \\
Non-lethal reinfarction (n (\%)) & & $3(21 \cdot 4)$ \\
After discharge: & 0 & 0 \\
$\quad$ Cardiac death (n (\%)) & 0 & \\
$\quad$ Non-lethal reinfarction (n (\%)) & & 0 \\
\hline
\end{tabular}

\section{Results}

PATIENTS PRESENTING WITH KILLIP CLASSES I TO III

Table 2 summarises the procedural characteristics and primary angiographic results. Large dissection with threatened reocclusion was the predominant indication for stenting in patients presenting with symptoms in Killip classes I-III (table 2). Stent implantation was primarily successful in $65 / 66(98 \cdot 5 \%)$ patients. Progressive thrombus formation within the stented segment caused technical failure in one patient. In this patient, neither repeat balloon inflations nor intracoronary administration of urokinase $(500000 \mathrm{IU}$ plus $5000 \mathrm{IU}$ heparin, over eight hours) could maintain vessel patency, as shown by repeat angiography after 12 hours. The patient survived on conservative treatment.

Figure 2 and table 4 summarise patient survival and major events. In addition to the patient with primarily unsuccessful stent implantation, two symptomatic stent reocclusions occurred during the in-hospital phase. Despite successful recanalisation of the stent, both patients had reinfarction, which was lethal in one. In addition one in-hospital death occurred because of sepsis and one because of progressive heart failure in a patient with a patent stent at necropsy. Cardiac out of hospital deaths were not encountered within six months of follow up; one patient died at day 101 after the intervention because bronchial carcinoma. None of the patients with symptoms of Killip classes I to III on admission underwent emergency cardiac surgery.

Angiographic follow up data were obtained for $59 / 66$ patients $(89.4 \%)$ after a median interval of 46 days (interquartile range 15-136 days). The reasons for missing studies were refusal by five patients and death in two patients. Repeat angiography revealed two silent reocclusions within the stented segment, both of which could be successfully recanalised by PTCA. Thus in patients with repeat angiography the rate of stent thrombosis, including initial technical failure, was $8 \cdot 5 \%$.

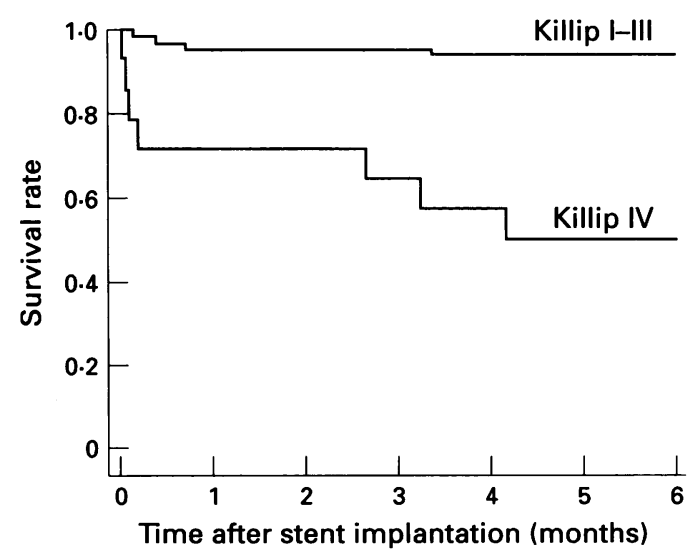

Figure 2 Kaplan-Meier curves presenting survival of patients with symptoms in Killip class I-III and of patients with symptoms in Killip class IV 
PATIENTS PRESENTING WITH KILLIP CLASS IV In all of the 14 patients presenting with Killip class IV, stenting was primarily successful (table 2). The main indication for stenting was failure to maintain TIMI grade 3 flow by PTCA alone (table 2).

Patient survival and major events are shown in fig 1 and table 4. Four in-hospital deaths occurred. One patient died within the catheterisation laboratory because of electromechanical uncoupling despite an open stent, one patient did not survive emergency cardiac surgery for papillary muscle rupture, and two patients died of progressive heart failure-one had had a reinfarction. Within six months after the intervention, three additional deaths occurred out of hospital because of progressive heart failure $(n=2)$ and sudden death. In the seven surviving patients, major clinical events, such as reinfarction or coronary bypass surgery, were not encountered. We obtained angiographic follow up in six of the surviving patients at a median of 19 days (interquartile range 16-27 days) after the intervention, which revealed a patent stent in each case.

\section{ROLE OF THROMBUS IMMEDIATELY BEFORE STENT DELIVERY AND OF ANTITHROMBOTIC REGIMEN}

Among patients with repeat angiography, stent implantation in the presence of visible thrombus was associated with a reocclusion rate of $3 / 25$ versus $2 / 40$ in the absence of thrombus $(P=0.58)$. Major clinical events were encountered in $5 / 29$ patients with visible thrombus immediately before stent delivery and in $6 / 51$ of those without $(P=0.73)$.

Stent thromboses did not occur in patients on antiplatelet therapy with ticlopidine. Moreover, all patients treated with ticlopidine survived the in-hospital period, and only one of these patients died ( 94 days) after the intervention. Among major complications, two surgical vascular repairs and one transfusion were required in 50 anticoagulated patients, while in 30 patients treated with ticlopidine one bleeding required transfusion $(P=0.99)$. Cerebrovascular accident was not encountered in either group.

\section{Discussion}

The study is the first to report extensive clinical experience with intracoronary stents in patients with acute myocardial infarction. It demonstrates that implantation of an intracoronary stent is safe and effective in optimising coronary artery patency after complicated PTCA. Intracoronary stenting fully restored coronary flow across the recanalised vessel in all but one patient $(98.8 \%)$ with reduced coronary blood flow, acute reocclusion, or large dissection with threatened reocclusion. Thus the primary technical success rate of stenting in acute myocardial infarction was similar to that in elective stenting. ${ }^{37} 38$ Contrary to common conjecture, the benefit from coronary stenting was not negated by abundant reocclusions.
OUTCOME IN PATIENTS WITH SYMPTOMS OF KILLIP CLASSES I TO III

In patients with symptoms of Killip classes I to III, repeat angiography at a rate of $89.4 \%$ revealed an occluded stent in $8.5 \%$ of the patients. Even though our patients were selected for a high risk of vessel closure, this reocclusion rate was lower than in mixed populations undergoing direct PTCA for acute myocardial infarction. ${ }^{10-12}$ Moreover, the reocclusion rate after coronary stenting in acute myocardial infarction was within the published range of $6.9 \%$ to $17 \%$ for the rate of subacute thrombosis after bail-out stenting in elective PTCA. ${ }^{1819} 34$ The clinical outcome of coronary stenting in acute myocardial infarction corresponds to the favourable angiographic results. After one month, the combined rate of reinfarction and death after stenting in patients with symptoms of Killip class I to III was $6 \cdot 1 \%$. This event rate contrasts to the known poor prognosis of failed direct PTCA. ${ }^{7-9}$ It is close to the range of $3.4 \%$ to $5 \cdot 1 \%$ for the rate of death and reinfarction reported in recent controlled trials on direct PTCA in acute myocardial infarction. ${ }^{4-6}$

\section{OUTCOME IN PATIENTS WITH SYMPTOMS OF KILLIP CLASS IV}

The study suggests that the benefit from coronary stenting after failed direct PTCA may be even larger in patients with cardiogenic shock. Using coronary stents, we achieved complete coronary artery patency in all of our 14 patients with Killip class IV symptoms, despite the initial failure of direct PTCA, and 10 of them could be discharged from hospital alive. The corresponding in-hospital survival rate of $71 \%$ is better than the $54 \%$ derived from pooled analysis of unselected patients undergoing direct PTCA for cardiogenic shock. ${ }^{2}$ Nevertheless, mortality of our patients with Killip class IV symptoms remained high and repeat angiography was obtained in only $43 \%$ of them. Thus the reocclusion rate of stents implanted in patients with Killip class IV symptoms remains uncertain. A patent stent was, however, found in all of these patients with repeat angiography and only one of the patients who died had clinical evidence of stent closure. We, therefore, have no reason to assume that the reocclusion rate in patients with Killip class IV symptoms precludes the use of stents in this setting.

\section{STENTING PROCEDURE AND ANTITHROMBOTIC} TREATMENT

It is generally believed that in the presence intracoronary thrombus the stent may exacerbate the pathological process. ${ }^{25} 26$ The present study shows that visible intracoronary thrombus after direct PTCA does not represent a contraindication to coronary stenting. Intracoronary thrombi before stenting were visible in a substantial number of our patients. However, this was not associated with a significantly increased rate of reinfarction and death. Moreover, intracoronary thrombus was a poor predictor of subacute stent reocclusion. 
We did not use intravascular ultrasound to optimise stent deployment. However, we did use high inflation pressures and large balloon to vessel ratios. ${ }^{31-33}$ Moreover, we took care always to cover the entire dissection with stents, ${ }^{22}{ }^{33}$ using multiple stents in more than half of the patients. These measures may have improved stent delivery and thus have helped to keep the rate of subacute reocclusion within an acceptable range. ${ }^{31-33}$

In contrast to previous anecdotal reports, ${ }^{26-28}$ coronary stenting in acute myocardial infarction does not require fibrinolytic or special antithrombotic treatment. Except for one patient with acute stent occlusion, we did not use fibrinolytic agents and in most of the patients the anticoagulation regimen was comparable to that used after elective stenting. ${ }^{1834}$ More recently, antiplatelet therapy with ticlopidine in addition to aspirin replaced the established anticoagulation regimen in 30 patients. Even though none of the patients treated with ticlopidine suffered death, reinfarction, or reocclusion in hospital, the study does not provide sufficient evidence to suggest that the antiplatelet approach is superior to anticoagulation. Optimal antithrombotic treatment remains to be established by future randomised trials.

\section{LIMITATIONS OF THE STUDY}

The study was designed as an initial investigation of the feasibility of coronary stenting in acute myocardial infarction. Accordingly, we did not randomise or compare our patients with a control group of patients not receiving stents. The impact of stenting on early and late outcome of patients with failed direct PTCA, therefore, can only be inferred by comparison with published outcomes of similar patient populations managed without stenting. In demonstrating that coronary stenting is an effective and sufficiently safe adjunct to direct PTCA in acute myocardial infarction, the present study breaks the ground for controlled trials that are needed of this approach.

Timing of angiographic follow up was quite heterogeneous. It was guided by the patient's recovery, the need for further interventions at non-infarct vessels, and by the uncertainty about the fate of a coronary stent in a vessel critical to patient survival. Nevertheless, we kept a minimal interval of two weeks between stenting and repeat angiography. This interval covers the period of time during which subacute stent thromboses typically occur. ${ }^{18}$ The design of the study, therefore, allows reliable assessment of the rate of subacute reocclusion. Analysis of the rate of chronic restenosis, however, was beyond the scope of the present study.

\section{CLINICAL PERSPECTIVES}

Failure of direct PTCA in acute myocardial infarction represents a serious therapeutic dilemma. $^{7-9}$ Among the approaches that have been pursued in this situation, emergency coronary bypass surgery carries a high risk for the patient ${ }^{39}$ and imposes an enormous logistic burden on the institution. Prolonged intracoronary thrombolysis, on the other hand, is of limited efficacy, ${ }^{40}$ since it usually cannot abolish the underlying pathology, such as dissection, and may substantially increase the risk of bleeding and access site complications.

The present study establishes that coronary stenting is a treatment option for suboptimal results of direct PTCA that is both safe and efficacious. The precise indication for coronary stenting as an adjunct to direct PTCA and the optimal adjuvant antithrombotic therapy remain to be determined. At present, however, the coronary stent may be regarded as a useful tool to restore coronary patency after complicated direct PTCA, provided the institutional expertise and the target vessel anatomy allow safe implantation.

1 Becker RC. Toward achieving optimal reperfusion: revisiting thrombolysis. Coron Artery Dis 1994;5:717-22.

2 Stone GW, Grines CL. Is there a role for percutaneous transluminal coronary angioplasty without antecedent thrombolysis in the treatment of acute myocardial infarction? Cardiol Rev 1994;2:98-111.

3 Simes RJ, Topol EJh, Holmes DR, Harvey DW, Rutsch WR, Vahanian A, et al for the GUSTO-I Investigators. Link between the angiographic substudy and mortality outcomes in a large randomized trial of myocardial reperfusion. Importance of early and complete infarct artery reperfusion. Circulation 1995;91:1923-8.

4 Grines CL, Browne KF, Marco J, Rothbaum D, Stone GW, O'Keefe J, et al. A comparison of immediate angioplasty with thrombolytic therapy for acute myocardial plasty with thrombolytic therapy for acu
infarction. $N$ Engl $\mathcal{G}$ Med 1993;328:673-9.

5 Ziilstra F, De Boer MJ, Hoorntje JCA, Reiffers S, Reiber JHC, Suryapranata H. A comparison of immediate coronary angioplasty with intravenous streptokinase in acute myocardial infarction. N Engl f Med 1993;328:680-4.

6 De Boer MJ, Hoorntie JCA, Ottervanger JP, Reiffers S, Suryapranata H, Zijlstra F. Immediate coronary angioplasty versus intravenous streptokinase in acute myocardial infarction: left ventricular ejection fraction, hospital mortality and reinfarction. $\mathcal{f}$ Am Coll Cardiol 1994;23: 1004-8

7 Ellis SG, O'Neill WW, Bates ER, Walton JA, Nabel EG, Topol EJ. Coronary angioplasty as primary therapy for acute myocardial infarction 6 to 48 hours after symptom onset: report of an initial experience. $\mathcal{F} \mathrm{Am}$ Coll Cardiol 1989;13:1122-6.

8 O'Keefe JH Jr, Rutherford BD, McConahay DR, Ligon RW, Johnson WL, Giorgi LV, et al. Early and late results of coronary angioplasty without antecedent thrombolytic therapy for acute myocardial infarction. $A m \ngtr$ Cardiol therapy for acute

9 Bedotto JB, Kahn JK, Rutherford BD, McConahay DR, Giorgi LV, Johnson WL, et al. Failed direct coronary angioplasty for acute myocardial infarction: in-hospital outcome and predictors of death. $F$ Am Coll Cardiol 1993;22:690-4.

10 Stone GW, Rutherford BD, McConahay DR, Hartzler GO. Direct coronary angioplasty in acute myocardial infarction: outcome in patients with single vessel disease. f Am Coll Cardiol 1990;15:534-43.

11 O'Neill WW, Timmis GC, Bourdillon PD, Lai P, Ganghadarhan $\mathrm{V}$, Walton $\mathrm{J} \mathrm{Jr}$, et al. A prospective randomized clinical trial of intracoronary streptokinase versus coronary angioplasty for acute myocardial infarction. $N$ Engl ₹ Med 1986;314:812-8.

12 Kahn JK, Rutherford BD, Johnson WL, Giorgi LV, Shimshak TM, Ligon RW, et al. Catheterization laboratory events and hospital outcome with direct angioplasty for acute myocardial infarction. Circulation 1990;82: $1910-5$.

13 Wall T, Mark DB, Califf RM, Collins G, Burgess R, Skelton TN, et al. Prediction of early recurrent myocardial ischemia and coronary reocclusion after successful dial ischemia and coronary reocclusion after successful thrombolysis: a qualitative and quantiol

14 Grines CL, Topol EJ, Bates ER, Juni JE, Walton JA, O'Neill WW. Infarct vessel status after intravenous tissue plasminogen activator and acute coronary angioplasty: plasminogen activator and acute coronary angioplasty:

prediction of clinical outcome. Am Heart f 1988;115:1-7.
15 Ellis SG, Roubin GS, King SB III, Douglas JS Jr, Weintraub WS, Thomas RGT, et al. Angiographic and clinical predictors of acute closure after native vessel coronary angioplasty. Circulation 1988;77:372-9.

16 Herrmann WRM, Foley DP, Rensing BJ, Rutsch W, Heyndrickx GR, Danchin N, et al. Usefulness of quantitative and qualitative angiographic lesion morphology, and clinical characteristics in predicting major adverse 
cardiac events during and after native coronary balloon angioplasty. Am $\mathcal{f}$ Cardiol 1993;72:14-20.

17 Sigwart U, Urban P, Golf S, Kaufmann U, Imbert C Fischer A, et al. Emergency stenting for acute occlusion after coronary balloon angioplasty. Circulation 1988;78: 1121-7.

18 Schömig A, Kastrati A, Mudra H, Blasini R, Schühlen $H$ Klauss V, et al. Four-year experience with Palmaz-Schat stenting in coronary angioplasty complicated by dissection with threatened or present vessel closure. Circulation 1994;90:2716-24.

19 Herrmann HC, Buchbinder M, Clemen MW, Fischman $\mathrm{D}$, Goldberg S, Leon MB, et al. Emergent use of balloonexpandable coronary artery stenting for failed percutaneous transluminal coronary angioplasty. Circulation 1992;86:812-9.

20 Roubin GS, Agrawal SK, Dean LS. What are the predictors of acute complications following coronary artery stenting? Single institutional experience [abstract]. $\mathcal{F} \mathrm{Am}$ Coll Cardiol 1991;17:281A

21 Serruys PW, Strauss BH, Beatt KJ, Bertrand ME, Rickards $\mathrm{AF}, \mathrm{Meier} \mathrm{BM}$, et al. Angiographic follow-up after placeAF, Meier BM, et al. Angiographic follow-up after placement of self-expand

22 Haude $M$, Erbel $R$, Issa $H$, Straub U, Rupprecht $H J$, Treese $\mathbf{N}$, et al. Subacute thrombotic complications afte intracoronary implantation of Palmaz-Schatz stents. $A m$ Heart F 1993;126:15-22.

23 Sutton JM, Ellis SG, Roubin GS, Pinkerton CA, King SB, Raizner AE, et al. Major clinical events after coronary stenting. The multicenter registry of acute and elective Gianturco-Roubin stent placement. Circulation 1994 89:1126-37.

24 Nath FC, Muller DWM, Ellis SG, Chapekis AT, Zimmermann C, Topol EJ. Early thrombotic occlusion of coronary stents: frequency, predictors, therapy and clinical outcome [abstract]. Circulation 1991;84Supp II:II-301.

25 de Jaegere P, de Feyter PJ, Serruys PW. Intracoronary stenting. In: Topol EJ, Serruys PW, eds. Current review of interventional cardiology. Philadelphia: Current Medicine; 1994;8:1-17.

26 Heuser RR. Breaking the barrier: stenting in acute myocardial infarction. Cathet Cardiovasc Diagn 1994;33:46.

27 Cannon AD, Roubin GS, Macander PJ, Agrawal SK Intracoronary stenting as an adjunct to angioplasty in acute myocardial infarction. F Invas Cardiol 1991;3:

28 Wong PHC, Wong CM. Intracoronary stenting in acute myocardial infarction. Cathet Cardiovasc Diagn 1994;33: 39-45.
29 Chesebro JH, Knatterud G, Roberts R, Borer J, Cohen LS, Dalen $\mathrm{J}$, et al. Thrombolysis in myocardial infarction (TIMI) Trial, Phase I: a comparison between intravenous tissue plasminogen activator and intravenous streptokinase: clinical findings through hospital discharge. Circulation 1987;76:142-54.

30 Killip T, Kimbal JT. Treatment of myocardial infarction in a coronary care unit: a two year experience in 250 patients. Am F Cardiol 1967;20:457-62.

31 Mudra H, Klauss V, Blasini R, Kroek M, Rieber J, Regar $\mathrm{E}$, et al. Ultrasound guidance of Palmaz-Schatz intracoronary stenting with a combined ultrasound balloon catheter. Circulation 1994;90:1252-61.

32 Nakamura S, Colombo A, Gaglione A, Almagor Y, Goldberg SL, Maiello L, et al. Intracoronary ultrasound observations during stent implantation. Circulation 1994;89:2026-34.

33 Colombo A, Hall P, Nakamuro S, Almagor Y, Maiello L, Martini G, et al. Intracoronary stenting without anticoagulation accomplished with intravascular ultrasound guidance. Circulation 1995;91:1676-88.

34 Schatz RA, Baim DS, Leon $M$, Ellis SG, Goldberg $S$, Hirshfeld JW, et al. Clinical experience with the PalmazSchatz coronary stent. Initial results of a multicenter study. Circulation 1991;83:148-61.

35 Jordan C, Carvalho H, Fajadet J, Cassagneau B, Robert G, Marco J. Reduction of subacute thrombosis rate after coronary stenting during a new anticoagulant protocol [abstract]. Circulation 1994;90Suppl 1:125.

36 Gawaz M, Neumann F-J, Ott I, May A, Rüdiger S, Schömig A. Effekt der antithrombotischen Behandlung auf die Thrombozytenfunktion nach Stentimplantation [abstract]. $Z$ Kardiol 1995;84Suppl 1:144.

37 Serruys PW, de Jaegere P, Kiemeneij F, Magaya C, Rutsch W, Heyndrickx G, et al. A comparison of balloonexpandable-stent implantation with balloon angioplasty
in patients with coronary artery disease. $N$ Engl $\Im$ Med 1994;331:489-95.

38 Fischman DL, Leon MB, Baim DS, Schatz RA, Savage $\mathrm{MP}$, Detre $\mathrm{K}$, et al. A randomized comparison of coronary-stent placement and balloon angioplasty in the treatment of coronary artery disease. N Engl $f$ Med 1994;331:496-501.

39 Montoya A, Mulet J, Pifarre R. Hemorrhagic infarct following myocardial revascularization. $\mathcal{F}$ Thorac Cardiovasc Surg 1978;75:206-12.

40 Gulba DC, Daniel WG, Simon $R$, Jost $S$, Barthels $M$, Amende I, et al. Role of thrombolysis and thrombin in patients with acute coronary occlusion during percutaneous transluminal coronary angioplasty. $\mathcal{f} \mathrm{Am}$ Coll Cardiol 1990;16:563-8. 